Delft University of Technology

\title{
Case Studies and Monitoring of Deep Excavations
}

\author{
Korff, Mandy
}

\section{Publication date}

2017

Document Version

Accepted author manuscript

Published in

Proceedings of the 9th International Symposium on Geothecnical Aspects of Underground Construction in Soft Ground- TC-204 ISSMGE

\section{Citation (APA)}

Korff, M. (2017). Case Studies and Monitoring of Deep Excavations. In Proceedings of the 9th International Symposium on Geothecnical Aspects of Underground Construction in Soft Ground- TC-204 ISSMGE: April 4 and 5, 2017, Sao Paulo, Brazil

\section{Important note}

To cite this publication, please use the final published version (if applicable).

Please check the document version above.

Other than for strictly personal use, it is not permitted to download, forward or distribute the text or part of it, without the consent of the author(s) and/or copyright holder(s), unless the work is under an open content license such as Creative Commons.

Takedown policy

Please contact us and provide details if you believe this document breaches copyrights.

We will remove access to the work immediately and investigate your claim. 


\title{
Case Studies and Monitoring of Deep Excavations
}

\author{
M. Korff \\ Deltares / Delft University of Technology, Delft, Netherlands
}

\begin{abstract}
Several case histories from Dutch underground deep excavation projects are presented in this paper, including the lessons learned and the learning processes involved. The focus of the paper is on how the learning takes places and how it is documented. It is necessary to learn in a systematic and active way from real and on-going projects because of the high failure costs in the industry, not excluding the underground construction part of it.
\end{abstract}

\section{INTRODUCTION}

Individuals and project-based organizations in the construction industry can learn in a (more) systematic way from case studies and monitoring of underground construction works. Underground construction projects did not suffer less failure costs than other parts of the construction industry. For example the Boston Big Dig, The Channel Tunnel Rail Link and the Amsterdam North South Line are well known projects for their cost overruns, partly also due to failure costs. This makes this subset of projects suitable for learning in general as well as evaluation of the learning process.

\section{FAILURE COSTS AND THEIR ORIGIN}

\subsection{International projects}

A detailed summary of failure costs is presented by Kazaz et al. (2005) and shows that failure costs in construction projects can range between $2 \%$ and $25 \%$ of the overall project cost. Research in the United States shows that inefficient management practices in projects (often referred to as failure costs) in the construction industry are over $12 \%$ of the total turnover of the industry (Burati et al. 1992 based on research for the Construction Industry Institute in 1989). Research carried out in the Netherlands (USP Marketing Consultancy, 2008) amounts to failure costs of $11.4 \%$ of the industry's turnover compared to $7.7 \%$ seven years earlier. Other studies into failures costs come up with comparable numbers; $5.5 \%$ to $11 \%$ of the production costs for apartment buildings (Hansen, 1985) and $2.3 \%$ to $9.4 \%$ on seven building projects in Sweden between 19941996 (Josephson and Hammarlund, 1999). Australian projects were analysed by Love (2002), who derived direct and indirect rework costs to be 6.4 and $5.6 \%$ of the original contract value.

Not many studies focused on projects related to underground construction. Avendano Castillo et al. (2010) identified for underground project that ground uncertainty and the interpretation of ground parameters plays a prime role in the occurrence of failure costs. According to the experts they interviewed, failure costs in underground related projects represent on average $4 \%$ to $6 \%$ of the total project costs. Although they state that failure costs to the client were much higher, the values given here seems low in comparison to the general values from the construction industry presented above.

\subsection{Causal analysis of failure costs}

In the majority of the cases failure costs share common causes (Love \& Li 1999 and Love \& Li 2000). The top 3 reasons for the costs of failure mentioned by USP Marketing Consultancy (2007) are 'lack of communication and information transfer', 'inadequate attention for feasibility during design phase' and 'the delivery of quality to end user as not being the highest priority'. Hall and Tomkins (2000) identified that the majority of incidents were attributable to errors and mistakes by specific individuals (22\%) or to supplier errors (27\%). "Force majeure" type incidents were very rare (2\%). Management and communication problems by the main contractor totalled $25 \%$ of the incidents. A number of potential improvements were identified, including amongst oth- 
ers the identification of common and recurring mistakes and errors that could be considered at the beginning of future, similar projects and better consideration of the training needs and meeting training targets of employees. The UK National Economic Development Office (NEDO) analysed "qualityrelated events" in building projects and found that design and poor workmanship together formed more than $90 \%$ of the total events investigated. Under poor workmanship "lack of care" and "lack of knowledge" were the main causes. In design "unclear/missing information" and "design will not work" were identified as the major causes.

\subsection{Results of 50 deep excavations study}

Korff and van Tol (2013) describe the analysis of about 50 deep excavations in The Netherlands, for which a claim situation has arisen between 1995 and 2012. The aim of this paper was to analyse the cause of the failure costs more than the costs themselves. The main source of failure costs in technical sense was related to the retaining wall of the deep excavation, the rest more or less evenly distributed over the other parts of the structure and the surrounding structures.

In $34 \%$ of the cases some form of physical damage was caused to adjacent buildings, the other main aspects of failure include time delays, need for additional measures to prevent deformations and/or leakages. In cases like these, an important question usually is whether the problem is caused by the design or the execution of the project. Although not mentioned for each case, in most of the cases, the design played a crucial role in the origin of the failures. The designer of the wall (which can either be an engineering firm or a contractor in an integrated contract) often disregards the constructability of the project, often due to perceived liability issues.

The most important aspect of the failures related to the learning process is the extent to which the event was predictable or not. Predictable adverse events in practice actually occur, often due to insufficient knowledge of the designers, despite the deployment of appropriate personnel, risk assessments and design reviews.

Based on the work by Bea (2006), the failures were classified into predictable and unpredictable events. In the 50 projects analysed in The Netherlands, more than $60 \%$ of the failures was due to not (correctly) applying existing knowledge. Moreover in $24 \%$ of the cases the cause of the failure is qualitatively known, meaning that these kinds of failures are known, but it cannot be predicted exactly when and where they will occur. In only $13 \%$ of the cases was unknown knowledge the main reason, all the others were "predictable surprises" as described by Bazerman and Watkins (2004).

$$
\begin{aligned}
& \text { Unknown Knowables (UK) or } \\
& \text { Unknown Unknowables (UU) }
\end{aligned}
$$

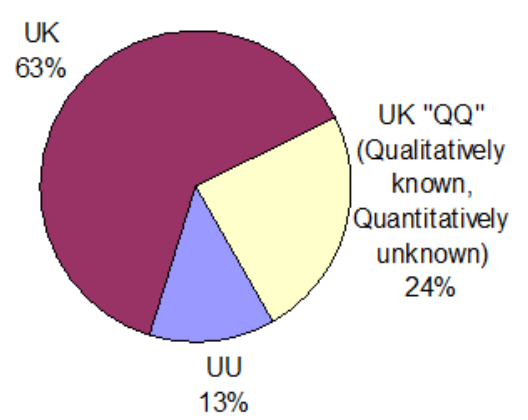

Figure 1 Subdivision in known and unknown knowledge (Korff and van Tol, 2013)

In total $87 \%$ of the cases failure could have been avoided. The use of proper risk management would have identified the risks, including those related to the knowledge of the staff working on the project. But a good risk management process needs to be fed with proper (geo)technical knowledge, which requires sufficient learning from individuals and organization. What do the results of these cases say about the learning process in the type of projects that were identified?

On an individual level it is hard to analyse these projects and determine the amount of learning that has taken place either due to the failure or in advance of it. The 50 cases surely had some amount of personnel that was involved in more than one of the projects or similar projects beforehand. It is however unlikely that the same mistake was made (or the same risk was missed) more than once by the same person.

On an organisational level however it is clear the projects apparently rely on the knowledge of the team rather solely. The fact that was established that in $60 \%$ of the cases the knowledge necessary to prevent the failure was present somewhere outside of the project shows clearly that learning from project to project is not taking place on a regular basis.

\subsection{The importance of knowledge and learning}

The importance of knowledge in the projects and with the professionals involved is also stressed by Bea (2006), who concluded that in many of the construction projects the identified failure costs could directly be related to (lack of) knowledge and development. 
The findings by Korff and Van Tol (2013) have shown that in Dutch underground construction projects the lack of application of existing knowledge could have prevented or limited failure costs in at least $60 \%$ of the cases.

A good example of learning from project to project is reported by Ball (1987), where a British contracting company managed to reduce total failure cost for a construction project from $4.1 \%$ of the tender amount to $0.6 \%$ for another project by studying the faults in the first project on the basis of trends to reveal the errors and preventing those errors in the second project.

Roberts (1991) found that by spending 1\% more on prevention efforts, the failure costs of construction can be reduced from $10 \%$ to $2 \%$.

The analysis of the causes for failure costs and the fact that over the last few decades no reduction has taken place in failure costs (not only in absolute terms but also not in relative terms) brings the author to the conclusion that, apart from the occasional project, learning from project to project does not or not sufficiently take place. Often this can be attributed to the widely present idea that in the construction sector each project is unique. This paper takes a more detailed look into the learning that can take place from case studies in underground construction.

\section{3 (GEOTECHNICAL) RISK MANAGEMENT}

The well known risk management cycle requires individuals and organizations to track risks during the course of a project, document them and use them in either the next stage of the project, or in a new project. Apparently, based on the 50 cases presented before, at least two systematic issues are often lacking:

1) Performing proper risk management (all the steps from figure 4 in a systematic, explicit way, based on technical expertise)

2) Evaluating and documenting the risks during the project for a next stage or project. (step DOCUMENT specifically).

Several authors have emphasized the need for proper risk management to prevent failures, for example Van Staveren (2006). In this article the focus however is on the learning from case studies and thus on the step where learning is made explicit, this is the DOCUMENT phase. It must be stated that documenting risks alone is not enough for a learning experience, but it is a necessary first step.
Figure 4. Risk management cycle

First, let's explore how this type of learning can be improved. Necessary aspects to increase the learning potential of real world projects include:

- Systematic learning process awareness

- Monitoring of project performance

- Documenting and sharing.

In the next sections, some examples are given of projects where systematic learning took place and each of the aspects above is analysed in more detail. Each example deals with underground construction works in densely populated areas, where monitoring of the construction performance played an important role.

\section{CASE STUDY PROJECT A2 MAASTRICHT}

\subsection{Project description}

The project comprised of the construction of the A2 road works in Maastricht, in the southern part of the Netherlands. A double stack cut and cover tunnel of $2 \mathrm{~km}$ length has been constructed in a highly variable soil with different quality chalk layers. The $10 \mathrm{~m}$ deep tunnel was constructed with steel sheet piles, three bracing levels and the bottom of the excavation was sealed off by the chalk. Most of the structures adjacent to the tunnel were found at distances of at least $20 \mathrm{~m}$, which made the project less risky for damage to these structures. The project itself was however very sensitive to the variations in the soil conditions. For this reason the observational method was applied, because also the chalk layers were difficult to characterize by site investigations. Details of the project can be found in Van Dalen (2015) and Galenkamp (2015).

\subsection{Risk awareness}

The design and construct contract put the responsibility of the main risks with the contractor, who in- 
vested heavily in monitoring and made a full implementation of the OM so observational method from the start of the project. Being rather a new concept for application in the Netherlands on such a scale and with the corresponding challenges in the site conditions, the contractor could only obtain permission for the construction with a very stringent risk management process, in which learning from earlier stages was required to safely excavate to more challenging parts of the project.

\subsection{Monitoring}

In application of the observational method the use of extensive monitoring equipment to track the performance of the structure is obviously essential. In this case monitoring involved deformations of the walls, forces in the struts and monitoring of the water levels on the inside and the outside of the tunnel. The monitoring was checked on a daily basis and partly automatically. Decisions to start work were made every day in the morning after inspection of the project and evaluation of the monitoring data.

\subsection{Documenting and learning}

Lessons learned in the project included:

- The observational method can successfully be used for underground construction works in case of soil heterogeneity, uncertainty in soil strength and deformation characteristics, when displacements are leading and in multistage processes.

- Optimization of a project with the OM is limited to what can be proven in time before the next construction phase takes place since some uncertainties can only be ruled out at a stage too late to use the benefits.

- Always expect everything to fail (in this case failure of the pumping system was reported as well as power cuts while the reserve generator was connected incorrectly as well as theft of (reserve) power cables.

- Increased monitoring efforts to optimize construction were intended to decrease the risk, but perceived by some of the workers as a sign that there actually was an increased risk.

The application of the Observational Method in this project resulted in a successful completion with much more optimistic soil parameters than the original design values, so the contingency measures were not used. This result was mainly obtained by a close cooperation between the contractor and the client in the Alliance form of the contract. There was increased awareness and transparency of the risk due to participation in a national applied research program (www.geoimpuls.org). The lessons learned in this project are collected in more detail in the new guideline for the OM application in the Netherlands, see SBRCURnet (2015).

\section{CASE STUDY NORTH SOUTH LINE AMSTERDAM}

\subsection{Project description}

The North-South line in Amsterdam is a $9.5 \mathrm{~km}$ metro line. The line starts at street level in the North of Amsterdam and passes under the historical center of the city in a $3.1 \mathrm{~km}$ twin shield tunnel. Five underground stations are constructed in deep excavations supported by diaphragm walls. The soil conditions are challenging due to the soft soils (clay, peat and sand) and the water table only decimetres below the surface. Old, historic and sometimes listed buildings are found at not more than 3-5 meters away from the tunnel. The construction of the line started in 2003 with preparation works for the stations, tunnelling commenced in 2009 and finished in 2011. The three inner city stations have been structurally finished in 2014. It is expected that the line will be fully operational in 2018.

\subsection{Risk awareness}

Risk management played an important role already from the start of the project. For example, a so called geotechnical base line report was made to understand and specify the risks related to varying soil conditions. Also the extensive monitoring system was part of this awareness.

During the excavation for one of the stations (Vijzelgracht Station), leakage through the wall resulted in large settlements of and damage to several monumental buildings, which threatened the support of the authorities for the project. With the application of robust preventive measures at two of the deep stations, it was possible to continue the project.

\subsection{Monitoring}

In order to determine the displacements of the historic structures along the deep stations an extensive, mostly automatic monitoring system was installed in the city centre from the year 2000. This included in total 74 robotic total stations for over 1700 prisms on the buildings (usually a minimum of 4 per building). Secondary instrumentation comprises of precise levelling points used as a backup system.

In order to handle the large amount of monitoring data, software applications have been developed with the use of GIS, see also Netzel \& Kaalberg (1999). The GIS has been developed to store, analyse, structure and visualise the data used in settle- 
ment risk management, in order to provide rapid reaction opportunities. The monitoring instruments further included extensometers behind the wall, inclinometers in the soil and in the wall and manual levelling of the surface and the buildings. Details of the monitoring system can be found in Korff and Kaalberg (2014) and in Kaalberg et al. (2003).

\subsection{Documenting and learning}

Lessons in this project were learned through the problems that took place as well as from the majority of the construction activities that went well.

\subsubsection{Organizational learning from problems}

It was learned that the organizational structure needed to be strengthened, with even more emphasis on the risk management process (by appointment of project leaders for each of the stations), the working methods as well as the (geo)technical quality of the personnel involved in both day-to-day construction control as well as independent reviewers. An important lesson was learned regarding communication: open communication with the community; house owners, shop owners and other inhabitants proved to create trust and understanding and built pride and goodwill within the community for the project.

The leakage events lead to a process of learning related to the construction of the diaphragm walls that were used. By analyzing the installation process and evaluating the quality of the walls upon excavation in a systematic way, with additionally a better theoretical understanding of the construction process with bentonite and concrete mixtures lead to important lessons. These lessons have been published in a guideline (CUR, 2010): Handbook Diaphragm walls:

1. Reporting on data in more detail. In case of calamities, these data are extremely useful to determine the cause. This also includes monitoring of the position of the grab, slump values of the truck mixer, inclination of concrete level and testing of the bentonite mixture with the soil from the site.

2. Ideal construction process involves desanding of the bentonite, cleaning of the trench, jetting of the joints, short time between removing steel stop end and concreting.

3. Perform proper risk management and prepare counter measures.

Furthermore, academic learning took place based on these events in the form of analysis of the concreting process (van Dalen, 2015) and the feasibility of sonic and geophysical logging to check the wall for potential leakages (Spruit, 2015).

\subsubsection{Organisational learning from ordinary con- struction}

A wealth of information was gathered by the very extensive monitoring system. Learning took place amongst others on the soil structure interaction between the excavation and the houses (Korff, 2013 and Frankenmolen 2006), the shield tunnel and the houses as well as the effectiveness of the compensation grouting that was used (Bezuijen et al. 2011). This lead to several guidelines, such as the design guideline for construction of deep excavations in inner cities (COB 2012) and validation of design methods. The outcome of the learning process related to the monitoring was documented in the monitoring evaluation report (COB 2016). Some of the lessons learned are presented here:

- Preliminary and installation related activities proved to be very disturbing and lead to large soil displacements $(60-70 \%$ of total soil displacements during construction)

- Old timber piles behave different than newer piles with sufficient end bearing capacity.

- The construction of the bored tunnel lead to very small settlements $(<2 \mathrm{~mm})$.

- Compensation grouting was effective in case of the Amsterdam saturated soil conditions for piles with their tip in the sand and not so effective in case of disturbed soil conditions.

The technical learning from the ordinary construction work was almost exclusively performed in cooperation with universities, placed besides the day to day activities and performed by different people. This was necessary to maintain focus on the academic learning and not on the more urgent project matters as well as to ensure the project progress was not hampered by the academic learning.

The non-technical learning that took place was gathered in several publications (Van der Kam, 2016 and Van der Kam et al., 2013) and a website (noordzuidlijnkennis.net) and preserved for use in other projects in the city of Amsterdam and beyond.

\section{CASE STUDY GEOBRAIN}

The last case study is in fact a database of projects collected in a period of about 10 years related to the installation of foundation elements, called GeoBrain (Hemmen, 2005, Mens et al. 2008). Over 30 industrial partners and contractors collected successes and failures in their projects in a systematic way to learn from the data. This resulted in over 3000 projects and analyses were performed on the database to get failure statistics such shown in Table 1. An 'experience' or 'observation' is uniquely defined by the type of element (for example sheet-pile or prefabricated concrete pile), the type of equipment used and 
the soil conditions present. Additionally to this digitalized data, also details concerning the building pit, the crew experience and the surroundings have been included. From all of the sheet pile installations, damage statistics were collected for 11 types of damage. From the potential damages, the sheet pile not reaching the required depth was the most common, which was recorded in $1.4 \%$ of the experiences. Since the database combines information on the type of sheet-pile, the installation equipment used and the soil conditions present, it is possible to predict the risk profile of a future project by searching for comparable experiences.

Table 1 Performance indicators of sheet pile installation projects in The Netherlands, collected on www.geobrain.nl on April, 26 2017. Total number of sheet piles installed is 106274 in a total of 818 collected experiences / (sub) projects

\begin{tabular}{|c|c|c|}
\hline \multicolumn{3}{|c|}{ Performance indicator } \\
\hline 1. & Damage & \\
\hline 2. & Number of sheet piling & \\
\hline 3. & Not achieving depth & 1.40 \\
\hline 4. & Damage to sheet piles & 0.40 \\
\hline 5. & Burned interlocks & 0.20 \\
\hline 6. & Breaking out elements & 0.20 \\
\hline 7. & Driven out of interlocks & 0.12 \\
\hline 8. & Lowering of adjacent piles & 0.24 \\
\hline 9. & Problems with hammer/vibrator & 0.03 \\
\hline 10. & Sloping of sheet piles & 0.16 \\
\hline 11. & Leakage through sheet piling & \\
\hline 12. & Sand transport through sheet & \\
\hline
\end{tabular}

The database was also used to validate current (analytical and numerical) prediction models for sheet pile installation as a second form of learning. The method of 'Receiver Operating Characteristic' was used, which was taken from medical sciences (Metz, 1978), to determine the quality of different models and to optimize parameters and variables in the model. 252 of the field observations (selected for their completeness) were compared for six different models (Mens et al. 2012). The model that ranked highest was the numerical Hypervib-I model (Holeyman et al. 1999), closely followed by the model with added expert knowledge. As an example the results of the expert knowledge system are presented in Figure 3.

Using project information from the GeoBrain observations database made it possible to validate the models and to attach a performance label to them, making it much easier for an engineer or designer to choose the right code.

From the GeoBrain experiences is was concluded that it is possible to learn from data collected in the field by contractors in different ways. The first and most accessible form of learning is the use of the database results directly to compare to future projects and thus determine the risks. The second, more ad- vanced type of learning is validating existing or even creating new models based on the data. This second type of learning however requires large amounts of data, literally hundreds of projects are needed to validate rather simple models with limited parameters, while thousands of projects are not enough for more complex models.

A positive by-product of the data collection was the shared interest of the clients and contractors involved, this process actually lead to better relations in the sector.

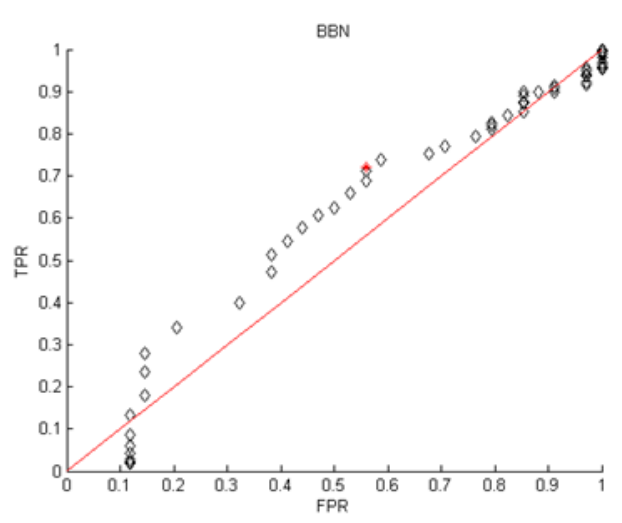

Figure 3 Receiver Operating Characteristic Curve for the validation of the GeoBrain expert knowledge system against the GeoBrain database for validation (graph from Mens et al 2012). FPR $=$ False Positive Ratio and TPR is True Positive Ratio

\section{LESSONS LEARNED FROM MONITORING OF DEEP EXCAVATIONS}

Based on the monitoring of the deep excavation projects presented in this paper, a list of generic lessons can be made. These lessons are drawn by a group of experts and written down in a publication (COB, 2016). A summary of the most generic lessons (not only related to the monitoring but to the project management of the projects as well) is given here:

1) Make sure you get as complete as possible a picture of the initial conditions of the project area; this helps to later identify and distinguish between failure mechanisms. Daily, seasonal and even more yearly phenomena can be identified. Needs to be set up by client. Important to choose the right area.

2) Discuss and make clear requirements about the distribution of the risk, which includes the risks related to the incompleteness of the knowledge about the initial conditions.

3) Working together with all stakeholders (project leaders, specialists, quality controllers, planners, workmen, supervision parties, insurance companies etc.) helps construction to move forward consistently, and safely, based 
on a shared trust in the work and the monitoring.

4) Be sensitive to the surroundings, proactive and communicate on the right level. Realistic communications work better than too optimistic ones. Interaction needs to be tailored to the stakeholders. Specialists can help understanding the work and the risks in smaller groups of stakeholders while general communication can be more generic. If questions arise, be as transparent as possible, also on technical details, because people interacting with urban deep excavations tend to educate themselves through various sources and often know much more about technical topics than expected at first.

5) Experience in the Dutch projects shows that dealing with damages in a generous instead of a strictly legal way significantly improves the perception of the project to its 'neighbours'. Contrary to the general belief, the budget necessary for such minor repairs is usually very small compared to the project budget.

6) Chose redundancy in your system; both in the monitoring system as well as in the project itself.

7) Get information out of your data; projects can be managed much more confidently and efficiently if monitoring data is used to provide real information on the risks. Usually monitoring provides indirect results and need to be worked by specialists to get a good picture of the actual risks.

\section{HOW ARE WE LEARNING?}

As the lessons given above were collected by experts in special discussion sessions and written down in a publically available report, this is not the only way learning takes place related to (deep excavation and other) projects. The first way people (both professionally and privately) learn is experiencing the hard way. If you have not taken on board the lessons of previous projects, things can go wrong to the point where projects get cancelled after construction has started. This way of learning can prove costly for the project concerned, but still be successful for future projects if the failures are analysed and the lessons implemented in new projects, as was the case for the diaphragm wall leakage in Amsterdam that lead to the use of innovative sonic logging in the Delft project, thus preventing at least one significant bad joint to cause trouble.

The second way of learning I would like to point out is a more rigorous one, not driven by a specific failure but by a deeper understanding of the need to learn from all experiences. By studying data extensively, systematically and consciously on a project or on a number of projects, valuable insights can be gained. The value of this kind of specialist analysis is not always recognized, while in the projects presented in this paper, this proved essential in understanding the mechanisms and taking right and effective measures. Once such analyses have been made, the next step is to share these together with the project meta data with others in the field. This requires a methodological data collection, which has become easier over the last few years due to new ICT tools. An essential part is also the sharing of the results in conferences, in public databases and other publications, such as (national or international) guidelines. Some guidelines have been published based on such analysis in the Netherlands the last few years; on monitoring, design of deep excavations, execution of diaphragm walls, etc. Last but certainly not least, for future engineers it is essential to start off with as much experience from practice as possible, so brining the project experiences into schools and university in the form of courses is recommended.

These methods of learning are all available to us every day. The big question however is: Are we learning enough? Some evidence is presented in this paper about the Dutch deep excavation projects. The last $5-10$ years reduction of risks has been an increasing priority. Risk management is a good tool to support this. Risk management however also clearly includes the very last step: the transfer of knowledge to future stages of the project of future projects. This step is most often the one that gets the least attention. And not surprisingly so, failure costs are still to high in our industry. The question remains if we can do better? Looking at other industries might provide us with an answer to that. For example the medical and ICT sectors have installed important concepts of learning in practice. From the medical sector we can learn that using check lists may at first seem bureaucratic or time consuming, but actually reduces the risks in surgeries (Treadwell et al. 2014). And how fast could the construction industry develop if we would learn with the speed of the ICT world? Using internet more widely and sharing knowledge much quicker is much more common there. In the ICT sector design patterns and anti-patterns are descriptions on how to do common things right and how to prevent common mistakes. These patterns are shared on the internet and ready to be used by everybody. Perhaps we could even imagine sharing full designs and construction plans in a similar way as an open source software project.

Learning is not only about having the right methods available, it is also a mindset. It requires reflection, integration of soft skills and hard skills and 
close cooperation between industry, projects and academia.

\section{CONCLUSIONS}

This paper has shown that there is a need to learn from past project experiences to reduce failure costs and to become a more effective industry. Each project that is being constructed provides a unique opportunity for learning.

One way of learning as presented here is learning systematically through collection and evaluation of actual experiences. Sharing of these experiences will speed up the learning process of the individuals and the whole system. To achieve learning organizations (specifically if they are project based) need to address and incorporate learning in their day to day work processes. Risk management provides a good framework for that, but is not always carried through completely to that stage. Increased learning potential can be obtained by systematically analyzing monitoring data and using this as validation or contravalidation of existing methods, knowledge and approaches. Other industries can provide the examples that show the potential for learning in a systematic way, but in the end people need to start building in reflection moments and processes.

The projects presented in this paper have all shown several different methods of learning and may be used for direct learning (for example through the lessons given in Chapter 7) or indirect learning (learning from the process of learning) for future projects.

\section{ACKNOWLEDGEMENTS}

The author wishes to thank the Centre for Underground Construction (COB) and the members of the T540 committee on the evaluation of the monitoring of recent large infrastructural projects; Hans Mortier, Thomas Bles, Joost Joustra, Jan van Dalen, Bjorn Vink and Erwin de Jong.

\section{REFERENCES}

Avendano Castillo, J.E., Al-jibouri, S.H. \& Halman, J.I.M. (2010) Underlying mechanisms of failure costs in construction; Challenges, Opportunities and Solutions in Structural Engineering and Construction - Ghafoori (ed.), Taylor \& Francis Group, London
Ball, P.L., (1987). The Economics and Assurance of Quality in Construction. Conference Paper, Quality: A Shared Commitment, EOQC, London, October.

Bazerman, M.H. and Watkins, M.D. (2004). Predictable surprises, the disasters you should have seen coming, and how to prevent them. Boston: Harvard School Press.

Bea, R., 2006. Reliability and Human factors in Geotechnical Engineering, Journal of Geotechnical Engineering and Geoenvironmental Engineering, ASCE, May, 2006

Bezuijen, A. Kleinlugtenbelt, R.E, Kaalberg, F.J. and Essler R.D. (2011), Settlement behaviour after compensation and corrective grouting, Proceedings of TC204, International Symposium, Geotechnical aspects of underground construction in soft ground, Roma, Italy.

Burati, J. L., Ledbetter, W. B., \& Farrington, J. J. (1992). Causes of Quality Deviations in Design and Construction. Journal Of Construction Engineering And Management, 118(1), 34-49. doi:10.1061/(ASCE)07339364(1992)118:1(34)

COB (2012) Aanbevelingen voor het ontwerp van bouwkuipen in stedelijke omgeving (design guideline for construction of deep excavations in inner cities) F530-ER-12-49785, Stichting COB, Gouda

COB (2016) Monitoring in de praktijk - Ervaringen grote infraprojecten (In Dutch). Delft, The Netherlands. Report can be downloaded from www.cob.nl/kennisbank.

CUR-report 231, 2010, Handbook Diaphragm-walls, design and installation, CUR/COB, Gouda, The Netherlands (in Dutch).

Frankenmolen, S. (2006) Analyse Noord/Zuidlijn monitoringsdata: Effecten van de beïnvloeding van de Holocene Laag op het zettingsgedrag van vooroorlogse panden. Master thesis TU Delft, Delft, The Netherlands

Galenkamp, H.F. (2015) Monitoring A2 tunnel Maastricht International Symposium on Geotechnical Safety and Risk (ISGSR), Rotterdam

Hall, M. and C. Tomkins (2001). "A cost of quality analysis of a building project: towards a complete methodology for design and build.' Construction Management \& Economics 19(7): 727.

Hansen, R., 1985. Kvalitetssikring og kvalitetskostnader, Hovedoppgave, Institute for anleggsdrift, Norges Tekniske Hogskole, Trondheim, Norway. (In Norwegian).

Hemmen, B.R. (2005) The synergy between theory and practice in geo-engineering. XVI international conference on soil mechanics and geotechnical engineering. Osaka, pp 28092811

Holeyman, A., Vanden Berghe, J.-F. and De Cock, S. (1999), Model Testing of vibratory driven piles, Proceedings of the XIth ECSMFE, Amsterdam, June 1999, Vol.2, pp. 769-776.

Josephson, P.-E. \& Y. Hammarlund (1999). "The causes and costs of defects in construction - A study of seven building projects." Automation in Construction 8(6):681-687.

Kaalberg, F.J., Braakman, S. and Cook, D.K. (2003) Amsterdam Noord/Zuidlijn: One of the largest settlement monitoring projects in Europe. FMGM2003.

Kazaz, A., M. and Talat B. (2005). "Cost-based analysis of quality in developing countries: a case study of building projects.' Building and Environment 40(10): 1356-1365.

Korff, M and Kaalberg, F.J. (2014) Monitoring dataset of deformations related to deep excavations for North-South Line in Amsterdam International Symposium on Geotechnical Aspects of Underground Construction in Soft Ground, Seoul, Korea

Korff, M and van Tol, A.F., (2013), Failure cost analysis of 50 deep excavations in The Netherlands

Korff, M. (2013) Response of piled buildings to the construction of deep excavations Ph.D thesis Cambridge University, Deltares Select Series, nr. 13 
Love, P.E.D. and H. Li (2000). "Quatifying the causes and costs of rework in construction." Construction Management and Economics 18: 479-490.

Love, P.E.D. and H. Li (1999). " Rework: a symptom of a dysfunctional supply-chain.' European Journal of Purchasing \& Supply Management 5(1): 1-11.

Mens AMJ, van Tol AF, Koelewijn AR (2008) Optimizing foundation engineering, validating models against experience using artificial intelligence. In: Singh DN (ed) IACMAG. Mumbai, India, pp 3384-3391

Mens, A. M. J., Korff, M., \& van Tol, A. F. (2012). Validating and Improving Models for Vibratory Installation of Steel Sheet Piles with Field Observations. Geotechnical And Geological Engineering : An International Journal, 30(5), 1085-1095. doi:10.1007/s10706-012-9506-5

Metz, C.E. (1978) Basic Principles of ROC Analysis. Seminars in Nuclear Medicine, Vol. VIII, No. No. 4 (October), pp 283-298.

National Economic Development Office (NEDO) (1983) Faster Building for Industry. NEDC, London.

Netzel en Kaalberg (1999) Settlement risk management with GIS for the Amsterdam North-South metroline. ITA-AITES World Tunnel Congress, Oslo

ProRail (2016) In één keer goed. De openstelling van de Willem van Oranjetunnel en station Delft

Roberts R. Quality does not cost - it pays. Australian Construction Law Report 1991;10(4):137-44.

SBRCURnet (2015) Handreiking observational method SBRCURnet, Delft

Spruit, R. (2015) To detect anomalies in diaphragm walls, PhD thesis TU Delft, Delft, The Netherlands

Staveren, M. v. (2006). Uncertainty and ground conditions : A risk management approach (1st ed.). Oxford: ButterworthHeinemann.

Treadwell JR, Lucas S, Tsou AY (2014) Surgical checklists: a systematic review of impacts and implementation. BMJ Qual Saf 23: pp. 299-318.

USP Marketing Consultancy bv. (2007). Gebrekkige communicatie grootste veroorzaker faalkosten,

USP Marketing Consultancy bv. (2008, April 11). Faalkosten in de bouw naar hoogtepunt. Rotterdam.

Van Dalen (2015) Observational method A2 tunnel Maastricht International Symposium on Geotechnical Safety and Risk (ISGSR), Rotterdam

Van Dalen, J. H., J.W, Bosch \& W. Broere (2015). Concrete Flow in Diaphragm Wall Panels: A Full-Scale In-Situ Test. International Symposium on Geotechnical Safety and Risk (ISGSR), Rotterdam

Van der Kam, S. (2016) De diepte in. Een leergeschiedenis van de drie diepe stations van de Noord/Zuidlijn (In Dutch). gemeente Amsterdam, Metro en Tram, Amsterdam

van der Kam, S., Weustink, T. and Cremer Eindhoven, R. (2013) Samenspel en tegenspraak. Tien lessen uit de Noord/Zuidlijn; published by project Noord/Zuidlijn, Dienst Metro, city of Amsterdam and King; Drukkerij Bokhorst, Nunspeet, The Netherlands.

Van Tol, A.F. and Korff, M. (2011) Deep excavations for Amsterdam metro North-South Line: an update and lessons learned International Symposium on Geotechnical Aspects of Underground Construction in Soft Ground, Rome 